Concepts and Frameworks in English for Specific Purposes

\title{
Reflections on the concept of discourse community
}

Le concept de communauté de discours : quelques réflexions

John M. Swales

\section{(2) OpenEdition}

Journals

Electronic version

URL: http://journals.openedition.org/asp/4774

DOI: $10.4000 /$ asp.4774

ISSN: 2108-6354

Publisher

Groupe d'étude et de recherche en anglais de spécialité

\section{Printed version}

Date of publication: 9 March 2016

Number of pages: 7-19

ISSN: $1246-8185$

Electronic reference

John M. Swales, "Reflections on the concept of discourse community », ASp [Online], 69 | 2016,

Online since 01 March 2017, connection on 10 December 2020. URL : http://journals.openedition.org/ asp/4774 ; DOl : https://doi.org/10.4000/asp.4774

This text was automatically generated on 10 December 2020.

Tous droits réservés 


\section{Reflections on the concept of discourse community}

Le concept de communauté de discours : quelques réflexions

John M. Swales

\section{Something of a personal history with the concept}

1 I first heard the term "discourse community" early in 1986, fairly soon after I had moved to the United States; it was used in a talk at the University of Michigan given by Lillian Bridwell-Bowles. I cannot remember much of the talk at today's distance, but I do remember how I immediately recognized that the concept of discourse community was precisely the concept I had been looking for since it would provide socio-rhetorical context for my ongoing exploration of (mainly) academic genres. By the time Genre Analysis was eventually published in 1990, discourse community (DC) had become a member of a trio of interlocking concepts, the other two being genre and languagelearning task (Swales 1990; Flowerdew 2015). For most of the next few years, I did not pay much attention to the concept, but I did keep mentioning to my doctoral students that the strange configuration of units in the small building where I had my office would make a splendid dissertation research site. This was because the North University Building (now demolished) had the university's Computer Center on the first floor, the university's Herbarium (its large collection of dried plants) on the second floor, while above it was the English Language Institute (ELI), divided into a teaching section and a testing section, and missioned to provide courses and services for international students on the large Ann Arbor campus. However, I was unable to persuade any of the students to take it on, so around 1995 I decided I would do the study myself. The basic idea was to see whether we had three different coherent and cohering discourse communities, each on its own floor in the same building. The book appeared in 1998 with the title of Other Floors, Other Voices: A Textography of a Small University Building (Swales 1998). I described the study as a "textography" to indicate 
that it was something more than a discourse analysis but something less than a fullblown ethnography.

One of the many things that I did learn in the investigative process was that university clocks move at different speeds in different parts of a university. The clock goes very slowly in the Herbarium. If a botanist wants to borrow some specimens from Michigan, he or she needs to agree to keep them for at least two years, and may actually keep them for decades. The reference books that the systematic botanists employ for keying out the plants they are studying have a shelf-life for decades. One major project, to describe all the plants of western Mexico, began in 1946 and was still continuing up to a few years ago. In the ELI, the shelf-life of its products, typically textbooks and tests, runs some 5-10 years or so before they are revised or replaced. While in the Computer Center, the shelf-life of computer manuals, etc., is often just a matter of months before an update appears or some patch is incorporated. Another discovery was that the botanists utilized a very different set of scholarly genres from those to which I had become accustomed; they were, in increasing order of importance or status, a "treatment" (a description of a selected group of plants), a "flora" (the description of all the plants in some region), and a "monograph" (a study of all the plants in one family, wherever they are found). Toward the end of the volume, I concluded that the denizens of the Herbarium formed a very distinct discourse community, while the ELI had many of the elements of a DC, even though there was a rather different ethos in the teaching and testing divisions (over such matters as to what "counts" as a publication), which remained a source of strain. On the other hand, in the Computer Center, the part-time employment of ever-changing streams of short-stay students meant that any sense of community, a sense that "we are all more or less on the same page", never really developed.

3 From then on, my thoughts about discourse communities lay largely dormant until in 2013 I was asked to give a talk at a well-known university in North Carolina. The professor who invited me suggested I speak about "the concept of discourse community", which I agreed to do. So I started to look around in order to bring myself up to date. My first surprise was that the old material in Genre Analysis seemed to be very much alive and well. The Wikipedia entry, for example, opens with this twosentence paragraph:

A discourse community is a group of people who share a set of discourses, understood as basic values and assumptions, and ways of communicating about their goals. Linguist John Swales defined discourse communities as "groups that have goals and purposes, and use communication to achieve their goals." ${ }^{1}$

Further, in the middle of this first page, we find:

Swales presents six defining characteristics:

A discourse community:

1) has a broadly agreed set of common public goals;

2) has mechanisms of intercommunication among its members;

3) uses its participatory mechanisms to provide information and feedback;

4) utilizes and possesses one or more genres in the communicative furtherance of its aims;

5) In addition to owning genres, it has acquired some specific lexis;

6) has a threshold level of members with a suitable degree of relevant content and discoursal expertise. ${ }^{2}$

5 If one scrolls down the Google entries for discourse community, it seems about a quarter consists of extracts from published or presented work, such as Beaufort (1998), 
Borg (2003), and Johns (1997). Another quarter consists of entries from encyclopediatype websites such as Researchomatic and the NCTE briefs. Most of the rest are either posts from instructors expounding the concept for their composition students, or blogs from those students, summarizing and applying the six criteria to their own experiences. One surprising aspect of these posts and blogs was that there were very few criticisms of or objections to the six criteria, one of the very few coming from a student named Jordan Rosa: "Questions I still have: Are these the only characteristics of a discourse community, or are there more? How many more?" Good for you, Jordan!

6 I soon discovered that the main reason for this flurry of activity in using the six old criteria derived from an extensive DC extract from Genre Analysis in Wardle and Downs' highly successful composition textbook Writing about writing: A college reader (Wardle \& Downs 2011). Here is a PowerPoint slide from one of the more interesting instructor uptakes by Heather Wayne, at that time a teaching assistant in English at the University of Central Florida. (I have added some explanatory notes in parentheses):

Using the 6 criteria, are these discourse communities?
1) A soccer team
2) A sorority/fraternity
3) UCF (University of Central Florida)
4) Publix employees (Publix is a supermarket chain in southeastern USA)
5) The Hong Kong Study Circle (a postal history group examined in Genre Analysis)
6) Republican voters
7) College Democrats at UCF
8) Composition scholars
9) Occupants of Nike dorms (a student resident hall)
10) Our class ${ }^{3}$

7 Not unexpectedly, I have been in somewhat of two minds about all this attention to the six defining criteria for a discourse community. (And I notice in passing that Wikipedia uses the present tense ("Swales presents") for something written twenty-five years ago.). On the one hand, there has been a sense of (doubtless vainglorious) gratification that something I had dreamed up in the late 1980s was still alive and well, while, on the other, there has been a feeling of dismay at the inertia-at the unthinking acceptance of something that was written before most of today's undergraduates were born and at a time before globalization, before all of those advances in computers and computerbased communications, and particularly before the emergence of social media.

\section{5 years later-a changed world}

The basic idea of a rhetorical discourse community arose in contrast to the longerstanding sociolinguistic concept of speech community. The latter was premised on a homogeneous assemblage of people who share place, background, language variety and who largely share social, religious, and cultural values. Such communities tend to be small and isolated, such as those existing in mountain villages, or on small islands, or in desert oases. In some contrast, the former is a largely heterogeneous, socio-rhetorical assemblage of people who broadly share occupational or recreational experiences, goals, and interests. Thus, members of a DC may have different first languages, different religions, and belong to diverse ethnicities. Examples might include members of GERAS or of TESOL, all those who work in an animal clinic, or those who are members of a local choir. 
9 However, it is unclear whether, in this era of cell-phones, family dispersion, a fluid and uncertain job market for the young, the rise of international trade, and the decline of local crafts and industries, traditional speech communities continue to exist in meaningful numbers. In addition, discourse communities both influence and are influenced by the larger communities within which they are situated. In consequence, when a university becomes established in a town, the presence of this constellation of discourse communities influences the wider urban environment; as a result, the urban environment provides services that are helpful to the university, such as cheap student housing, cheap restaurants, museums, and more bookshops, which in turn further consolidates our sense of a university town like Cambridge, Heidelberg, or Uppsala. And the same shaping forces create other kinds of town: religious ones like Lourdes, Assisi, or Mecca; sporting towns like Le Mans, St. Andrews, or Saratoga; or government towns like Washington, Ottawa, or Canberra. In other words, both concepts have developed fuzzier boundaries as the world has changed.

10 A second set of problems is that the concept of discourse community as originally conceived was overly static. While this perhaps did not matter so much in 1990, in today's more unsettled and uncertain world, it looms larger as a problem; in particular, the concept did not firmly or directly address how people either join or leave DCs. For this, it is helpful to turn to Lave and Wenger's "Community of practice" concept (Lave \& Wenger 1991), in which they explain the processes of entry, apprenticeship, membership, seniority, and exit through retirement, death, translocation, etc. A third problematic area is that both the discourse community concept and that of communities of practice tend to view their objects of study through an overly idealistic lens, especially in terms of assumptions about shared beliefs, values, motives, and allegiances among its members (Harris 1989). For instance, when we visit a department in the university that is new to us, our immediate impression is typically one of a homogeneous and sedate disciplinary world with wide agreements about such matters as methodology and epistemology. However, the more we get to know it, the more it seems to be fragmented and compartmentalized, and perhaps even fractious and adversative (Tannen 1998). To an outsider, a linguistics department, for instance, might seem to represent a collectivity of folks with a like-minded interest in language. However, to an insider, there are clear differences between a phonetician and a phonologist, or between those who pursue the relationship between language and mind, and those who pursue the relationship between language and society. Sometimes, of course, difference leads to fracture. As in a number of universities, the biology department at Michigan has split into two, one dealing with micro- and molecular biology and the other dealing with ecology and evolution. As a senior biologist said to me at the time of the split, "We biologists are either skin-in or skinout". Finally, like many in major U.S. universities, I used to have a split appointment: $50 \%$ of effort in the Department of Linguistics and 50\% in the English Language Institute. I suspect I was always a little too practical and pragmatic for my mostly theoretical linguistics colleagues, while a little too research-minded for my fellow EAP instructors in the ELI. 


\section{Three types of discourse community in academia}

11 The term discourse community is now more than thirty years old since it was apparently first coined by Martin Nystrand, a professor of English at the University of WisconsinMadison (Nystrand 1982). Since then, it has been widely used and discussed (sometimes critically) by scholars in applied language studies as a way of recognizing that communications largely operate within conventions and expectations established by communities of various kinds. As this interest in the concept has proliferated, we have come to see that these communities are, in fact, differentiated by various factors, such as how localized they are, what origins they have had, and what types of activity are central to their existence. So, it is the main purpose of this section to offer a categorization of different types of discourse community; if you will, to draw an outline map of the discourse community territory.

\section{Local discourse communities}

There are essentially three sub-types of these: residential, vocational, and occupational, but only the last of these really applies to the university context. These are groupings of people who all work at the same place (as in a factory or a university department), or at the same occupation in the same area (all the bakers in a town). These DCs have acquired many abbreviations and acronyms as well as some special words and phrases that are needed in order to get their jobs done more quickly and more efficientlyterminologies that are not used, nor even often understood, by the general public. For example, when I worked in Aston University, one of the main eating places on campus was the Vauxhall Dining Centre. So, when we had visitors, if I were not careful, I would say some form of "Let's go to the VD Centre for lunch". When I saw consternation on their faces, I would hurriedly have to explain that I was not suggesting eating at the clinic for venereal diseases!

13 I am, of course, familiar with my local discourse community in Michigan's ELI. I know when the building is unlocked and how to gain access when it is locked, where the toilets are, and who to ask for technical help. I know which codes to use for the photocopier, and where to find certain office supplies, and so on. However, when I travel to another university for a conference, I do not know any of these things and, unless the signage is excellent, I will probably soon get lost. Lower-level university staff typically belong to just their local departmental discourse community, while mid-level staff may belong in addition to the communities of, for instance, departmental budget officers, who get together for regular meetings and discussions. High-level administrators probably belong to some professional association and travel to that association's national convention. Members of these DCs also have acquired expectations and conventions of behavior that orchestrate their working days. One further consequence is that implicit value systems emerge which determine what is seen as good and less good work. Further, members of these DCs may get together socially outside of work, which further reinforces the community. Often, in these communities, there are apprentice arrangements (such as probationary periods) whereby new members are scrutinized as they attempt to acculturate into accepted occupational behaviors. 


\section{Focal discourse communities}

14 Focal communities are the opposite in many ways of local ones. They are typically associations of some kind that reach across a region, a nation, and internationally. They may be informal groupings or more formal ones with rules, elections and paid memberships. One informal group that I belong to is Southeast Michigan Birders, and this is part of an email message I received recently:

At about 3 p.m. yesterday three owls flew over Wisner Hwy. As they flew closer to the road they swooped lower and disappeared into the woods. Because of the open fields and time of day I suspected SEO, but thought probably not because I have never associated SEO with an affinity for landing in woods.

15 I suspect that I may be the only person reading this journal who would know that SEO is the standard U.S. acronym for short-eared Owl. Indeed, many types of discourse communities develop shorthand expressions, such as abbreviations and acronyms, to aid speed of communication. Members of such groups can be of different nationalities, ages, and occupations, and can differ quite considerably in their economic circumstances and educational backgrounds. They come together because of a focus on their hobby or recreational preference. Today, these kinds of DC are much aided by modern conveniences such as email and the cell phone. In some cases, they may produce a newsletter or have some other kind of publication that is distributed among the members.

16 The other major kind of focal discourse community is professional rather than recreational. In many professions, there has emerged over the years a national association that is designed to bind the members together and advance the profession in terms of protecting its rights and using its specialized expertise to lobby against what it views as ill-considered policies and in favor of those that it believes to be more soundly based. GERAS and BAAL (the British Association of Applied Linguists) would be typical examples. Many of these associations have a national conference, whereby individuals from far-flung places gather together to learn of latest developments, review the latest products in exhibition areas, and listen to luminaries in their field. These days, they typically have very active websites, wherein members can receive updates and express their opinions and preferences. If they are academically inclined, these associations often also support one or more journals for their members, such as ASp or TESOL Quarterly.

\section{"Folocal" discourse communities}

17 The third and final main type of discourse community has characteristics of both local and focal DCs, which is why I have coined the fused term "folocal" as a neologistic amalgam of the "local" and "focal". These are hybrid communities whose members have a double-and sometimes split-allegiance, as they are confronted by internal and external challenges and pressures. Consider the situation of the local branch of your bank, or a car dealership in your area. The people who work in such places have both their own ways of going about their tasks, and their own conventionalized ways of talking about those tasks and with their customers. However, they also are in contact and receive instructions from regional or national offices that in part determine how they carry out their duties. In effect, they are subjected to both centripetal and centrifugal forces. 
Perhaps a clearer instance is that of a university department in a research-active university. Members of such departments are members of both a local DC and a focal one. They understand how things operate in their own institution as they go about their teaching and administrative activities. Unlike outsiders, they know when rooms and buildings are locked, and where and to whom to make an application for some small amount of money. But they are also specialized scholars whose closest colleagues are likely to be elsewhere, perhaps even in other countries, and whose activities involve presenting at conferences in other places and publishing in distant journals. As is well known, there often emerges a conflict between the local demands on their time and the focal demands on that time-a conflict that is presumably becoming exacerbated as more and more higher education institutions are pressuring their faculty to publish in recognized international journals (Bennett 2014). These, then, are some of the typical competing pressures of belonging to a "folocal" discourse community.

\section{Discourse community and identity}

Many people are occasional members of more than one discourse community. In my own case, I am a member of the institute where I have had an office for the last thirty years, but also I am active in the wider world of English for Academic Purposes by, for instance, serving on a number of editorial boards. My current hobbies are birdwatching and butterfly-watching, and I belong to various associations that support these similar but not identical activities. In the past, I was a member of a focal DC that brought together a very disparate group of people who were interested in the postal history of Hong Kong, about a hundred philatelists from some twenty countries. Our student services secretary is a dedicated "Whovian" (i.e., a fan of the Dr Who TV program), and last year he flew to London to attend the Dr Who 50th Anniversary Celebration. As we move from one DC to another, our verbal and social behavior adapts to the new environment, but I do not believe that this necessarily implies that we adopt new identities, or that we are somehow merely an aggregation of different personae. (Unless, of course, we are spies or under-cover agents.) My beliefs about this were brilliantly exemplified (and with an astonishing economy of words, including but a single opening verb) by Alexander Pope:

See the same man, in vigour, in the gout;

Alone, in company; in place, or out;

Early at business, and at hazard late;

Mad at a fox-chase, wise at a debate;

Drunk at a borough, civil at a ball,

Friendly at Hackney, faithless at Whitehall.

Epistle 1: To Cobham, 1734 (Williams 1969: 162-163)

20 As Pope avers, it is "the same man" (or woman), healthy or ill, employed or not, at work or gambling, wild at sport or sensible in discussion, drunk at an election, goodmannered at a dance, reliable and amiable in the East End of London, but not to be trusted at the seat of the central government. 


\section{Reconsidering DC criteria}

21 Given the foregoing-ossified criteria for DCs, problems with the concept, and three contrasting types of discourse community-it is certainly time to re-imagine the concept itself, first by reflecting on the original six criteria and then more generally. In each case, I will give the Wikipedia summaries followed by updates.

\section{A DC has a broadly agreed set of goals}

A DC has a potentially discoverable set of goals. These may be publicly and explicitly formulated (as in "mission" or "vision" statements); they may be generally or partially recognized by its members; they may be broadly consensual; or they may be separate but contiguous (as when older and younger members have different ideas about the best future direction of the DC, or when there is a clash between academic researchers and practitioners, as in the just-holding-together American Psychological Association). This expansion then is designed to recognize that a DC is not necessarily utopian in flavor; it also acknowledges that DCs can flourish in darker worlds, such as those represented by Al-Q'aida, price-fixing cabals, or industry pressure groups.

\section{A DC has mechanisms of intercommunication among its members}

Fine, but we now need to emphasize the roles of new digital channels, such as emails, blogs, tweets, etc., and we also need to stress that without any means of intercommunication of any kind, there is no real community. Subscribers to Le Monde may share certain characteristics, but they do not form a discourse community.

\section{A DC uses its participatory mechanisms to provide information and feedback}

This third criterion was always sadly incomplete. A DC uses its participatory mechanisms to manage the operations of the DC and to promote (usually) recruitment, change, growth, and development, and to orchestrate (rarely) retrenchment and demise. In other words, these mechanisms are used to initiate actions and activities, rather than simply providing information. For instance, the employer and employees in a small shop may get together to discuss relocating; a London club may vote to admit women; or a university department, in a series of faculty meetings, may decide to drop a degree option because of low enrollment.

\section{A DC utilizes and hence possesses one or more genres in the communicative furtherance of its aims}

The use of "possesses" is rather strange as it soon becomes clear that there are not enough genres in the world for them to be "possessed" by individual DCs. A DC utilizes an evolving selection of genres in the furtherance of its sets of goals and as a means of instantiating its participatory mechanisms. These sets of genres are often particularized, as the genres are performed, re-performed, and refined, but they are 
rarely owned (i.e., uniquely the property of a particular DC). For instance, most university departments have regular staff meetings, but these evolve differently, with emerging differences about speaking and voting roles, about ancillary genres, such as agendas and minutes, and about allowable topics and interventions.

\section{In addition to owning genres, it has acquired some specific lexis}

A DC has acquired and continues to refine DC-specific terminology. Classically, this consists of abbreviations and shorthands of all kinds, not including various kinds of codes. For example, hospitals in the U.S. have a rich menu of codes that the staff employ, especially in emergencies, partly for efficiency and partly to keep information from patients and the general public. So, "code 236 on floor six" might indicate a heart attack on that floor. In the older ELI, when we still had a placement test, we might have said among ourselves of a new international student, "She looks like a 73 across the board". More widely, at the University of Michigan and indeed elsewhere, unofficial labels are common. Our football stadium is often referred to as "The Big House"; the central administration building is known as "the Mondrian cube" because of its architecture; and the Shapiro Library more often than not goes by its discarded old name "the UGLI" (the old name being "The Undergraduate Library"). Further, disciplinary terminology can be sui generis: recall that the classic genre set for systematic botany consists of treatment, flora, and monograph.

\section{A DC has a threshold of members with a suitable degree of relevant content and discoursal expertise}

27 A DC has an explicit or implicit hierarchy and/or structure which, inter alia, manages the processes of entry into and advancement within the discourse community. The stress here on managing DC affairs reduces the somewhat static impression that the 1990 formulation produces.

We can now add two new criteria.

\section{A DC develops a sense of "silential relations" (Becker 1995)}

A DC develops a sense of "silential relations" (Becker 1995), whereby there is a sense of things that do not need to be said or to be spelt out in detail in either words or writing. Bridge players invariably say "four clubs" rather than "I bid four clubs". Or consider the case of discoveries in the world of nature. If the discovery is of a large mammal, it will make the front pages of the world's major newspapers. If it is of a bird, it will merit an article, including pictures or perhaps a video, in a specialized journal (Gross 1990). But suppose we have a new plant; here is a typical write-up:

Bunchosia itacarensis W R Anderson, sp. nov.-Type: Brazil. Bahia: Mun. Itacaré, $3 \mathrm{~km} \mathrm{~S}$ of Itacaré, forest at edge of ocean, Dec fl, Mori et al. 13081 (Holotype: MICH! CEPEC, NY, not seen).

We only know that this is a discovery because of the laconic abbreviated Latin phrase sp. nov.; also note the interesting short hand convention in "MICH!" The exclamation mark indicates that the author has actually examined the University of Michigan specimen. 


\section{A DC develops horizons of expectation}

31 A DC develops horizons of expectation, defined rhythms of activity, a sense of its history, and value systems for what is good and less good work. Consider again the concept of the university clocks moving at different speeds that was discussed in the opening section. Or reflect on how DCs evolve rotas and rosters. Thus, in the ELI, every other Friday, somebody is responsible for clearing out the communal fridge; every so often, the administrative staff carry out a stock-taking; there is a fire-drill once a year, as well as a Christmas party; the first staff meeting of the year includes the director's review of the previous year, and so on.

Generally speaking, and with some flexibility, all eight criteria can usually be applied to all three types of community.

\section{So, where do we stand?}

It would seem that we can set up operable criteria for looking at groups in order to examine whether those groups qualify for DC status. On the other hand, actually defining discourse communities, or sub-types of them, has proved rather intractable; twenty years ago Bazerman observed that "most definitions of discourse community get ragged around the edges rapidly" (Bazerman 1994: 128), and today that situation has not greatly changed. And yet, it remains seductive, as Paul Prior explains:

Why does DC theory have such strange features: instant adoptability, resilience in the face of critique, resistance to calls for theoretical specification, the protean character of its fundamental assumptions as it migrates across theoretical and empirical traditions? (Prior 2003: 1)

It is doubtful, then, in present formulations that the concept is a robust social construct. A historian might argue that it does not account for economic and political forces; a sociologist might say that it fails to acknowledge the effects of broader social structures; an educationist might claim that it downplays acquisitional trajectories, as well as the roles of individual agency; and an anthropologist could argue that it ignores powerful aspects of cultural history. But I would counter-argue that this probably does not matter as long as our focus is on rhetorical principles of organization, on discoursal expectations, on significative linguistic tokens, and on intriguing textual extracts. Such attention on these more surface features provides insight into what at first sight might seem standard, ordinary and predictable. On this topic, I will give the last word to James Porter, whose important book is unfortunately little known outside the United States:

The term "discourse community" is useful for describing a space that was unacknowledged before because we did not have a term for it. The term realigns the traditional unities-writer, audience, text-into a new configuration. What was

before largely scene, unnoticed background, becomes foreground. (Porter 1992: 84)

It is precisely this foregrounding realignment that makes the DC concept useful for languages for specific and academic purposes, and for EAP and other practitioners as they work to give students the oracy and literacy skills to survive and flourish in their diverse educational environments. 


\section{BIBLIOGRAPHY}

BAZERMAN, Charles. 1994. Constructing Experience. Carbondale, IL: Southern Illinois University

Press.

BEAUFORT, Anne. 1998. Writing in the Real World: Making the transition from school to work. New York:

Teachers College Press.

BECKER, Alton L. 1995. Beyond Translation: Essays toward a modern philology. Ann Arbor, MI:

University of Michigan Press.

BENNETT, Karen (Ed.). 2014. The Semiperiphery of Academic Writing: Discourses, communities and practices. London: Palgrave MacMillan.

BORG, Eric. 2003. “Key concepts in ELT: Discourse communities”. ELT Journal 57/4, 398-400.

FLOWERDEW, John. 2015. “John Swales's approach to pedagogy in Genre Analysis: A perspective

from 25 years on". Journal of English for Academic Purposes 19, 102-112.

Gross, Alan G. 1990. The Rhetoric of Science. Cambridge, MA: Harvard University Press.

HARRIS, Joseph. 1989. "The idea of community in the study of writing”. College Composition and

Communication 40, 11-22.

Johns, Ann M. 1997. Text, Role and Context. Cambridge: Cambridge University Press.

LAVE, Jean \& Etienne WENGER. 1991. Situated Learning: Legitimate peripheral participation. Cambridge: Cambridge University Press.

NYSTRAND, Martin. 1982. What Writers Know: The language, process, and structure of written discourse. New York: Academic Press.

PORTER, James E. 1992. Audience and Rhetoric: An archaeological composition of the discourse community. Englewood Cliffs, NJ: Prentice Hall.

PRIOR, Paul. 2003. “Are communities of practice really an alternative to discourse communities?". Presentation at the American Association of Applied Linguistics Conference, Arlington, Virginia.

SWALES, John M. 1990. Genre Analysis: English in academic and research settings. Cambridge:

Cambridge University Press.

SwALES, John M. 1998. Other Floors, Other Voices: A textography of a small university building. Mahwah, NJ: Lawrence Erlbaum.

TANNEN, Deborah. 1998. The Argument Culture. New York: Random House.

WARDLE, Elizabeth \& Douglas Downs. 2011. Writing about Writing: A college reader. Boston: Bedford/ St. Martins.

Williams, Aubrey (Ed.) 1969. Poetry and Prose of Alexander Pope. Boston: Houghton Mifflin.

\section{NOTES}

1. <http://en.wikipedia.org/wiki/Discourse_community>

2. idem

3. idem 


\section{ABSTRACTS}

This article reflects upon my thirty-year intermittent involvement with the concept of discourse community. It opens with a personal history of that involvement, focusing on a study of the communities in a single, small university building. It then moves to the way the concept has become co-opted by those who teach university-level writing in the United States. Then, three types of discourse community are introduced: local, focal, and "folocal", this last having characteristics of the first two. Active academics are typically members of "folocal" communities, as they attempt to balance the demands of their local situation (teaching, administration) and the demands of active scholarship (presenting, publishing). In the second half of the paper, the original criteria as given in Genre Analysis (1990) are modified, extended, and brought more up to date, followed by some concluding observations.

Cet article présente une réflexion sur le concept de communauté de discours, dont, en tant que chercheur, je me préoccupe de manière épisodique depuis trente ans. Il retrace tout d'abord le point de départ de mon intérêt personnel pour cette notion, en rappelant les résultats d'une étude qui portait sur des communautés au sein d'un petit bâtiment universitaire. Il explore ensuite la façon dont ce concept a été repris par ceux qui enseignent les techniques d'écriture universitaire dans le supérieur aux États-Unis. Trois types de communauté de discours sont ensuite proposés : les communautés locales, focales et «folocales", ces dernières présentant des caractéristiques communes aux deux premières. Les universitaires particulièrement actifs appartiennent typiquement aux communautés «folocales » car ils s'efforcent de maintenir un équilibre entre les exigences qui émanent du contexte local (enseignement, tâches administratives) et celles qui sont liées à la production savante intensive (communications, publications). Dans la seconde partie de l'article, les critères dans Genre Analysis (1990) sont amendés, étoffés et mis à jour, puis sont suivis de remarques conclusives.

\section{INDEX}

Mots-clés: communauté de discours, critère définitoire, exploration textographique, révision des critères, type de communautés

Keywords: defining criteria, discourse community, revision of criteria, textographic exploration, type of community

\section{AUTHOR}

\section{JOHN M. SWALES}

John M. Swales is Professor Emeritus of Linguistics at the University of Michigan, where he was also Director of the English Language Institute. Over a lengthy career, he has authored or coauthored 20 books and about 130 articles and book chapters. jmswales@umich.edu 